Sidney Dyke

\section{Sidney Dyke}

\section{W R Timperley, J Burston, E Howl}

\section{An inspiration to us all!}

T he founding of the Association of British Pathologists (later the Association of Clinical Pathologists (ACP)) in 1927 was testimony to Dyke's professional standing and drive and was the springboard for his inspired leadership. During the course of his professional life and into retirement he had a profound and wholly beneficial influence on the practice of pathology in the UK, in Europe, and in much of the world

Sidney Campbell Dyke was born on 5 September 1886 and died on 3 March 1975, aged 88. His early life was complicated, his father having gone to Canada, leaving him to live with his father's brother, Edward. His aunt Kate, Edward's wife, had lost her only son at the age of 14, one year before Sidney was born, and it seems likely that she conferred some of her affection for her son to Sidney. He certainly grew up to be a warm and loving person himself and somebody must have encouraged his interest in books and reading. It is said that one of his earliest sayings was "me wants to learn"- a trait that lasted all his life. He went to the village school, wearing skirts, as was usual for boys up to the age of 5, and remembered his fear of the geese on the common he had to cross because they pecked his legs.

\section{"During the course of his professional life and into retirement he had a profound and wholly beneficial influence on the practice of pathology"}

His sister, who visited every summer, remembered life at Taplow as an eternal golden Edwardian summer. Uncle Edward had a houseboat, two punts, and a canoe. There was tennis and bathing. Sidney remembered Boulter's lock crammed with punts, full of smart young men in blazers and boaters, and beautiful girls with parasols. But the position of Sidney and his elder brother Gordon in their uncle's household was somewhat equivocal. They were treated very much as poor relations, eating with the staff in the servant's hall where Sidney became very devoted to the coachman Talbot.

Edward ran a lucrative private school in Taplow, known as Taplow Grammar School. The school was subsequently sold and with the proceeds Edward successfully invested in land and housing and bought a large house called "Beechwood".

Sidney's father, John, had worked his way across Canada to British Columbia, leaving his wife as "head nurse" in an Irish country house, after the final collapse of his fortunes in an unsuccessful attempt to run a brewery in Dublin, in which Edward had set him up as manager. Thinking that British Columbia would be a good place to settle, his brother Edward and his daughter Laurie went out there to buy a 20 acre farm in the Frazer valley, near Port Haney. His wife and children followed at intervals afterwards. This seems to have been rather a disastrous purchase; the land consisting largely of tree stumps after the woods had been felled. Sidney Dyke recalled the thrill of stuffing a tree stump with gunpowder, lighting the fuse, and then running "like hell".

The transition to a flea ridden $\log$ cabin in the Frazer valley in 1899, aged 12 , must have come as a shock. He was sent alone across the Atlantic with his 14 year old brother from Tilbury to Ottawa on "harvesters tickets" costing £5, sleeping on a straw paliasse, covered with red cotton, which stained his face pink.

Not long after his arrival in Canada uncle Edward, who had recognised his potential, arranged for him to attend New Westminster High School and board locally. Sidney broke away from his family at this stage and was never close to them again.

At school he founded and co-edited the school magazine, The Pharos, and when he matriculated he won the "Governor-General's Gold Medal".

After leaving school he worked for a short time on the New Westminster Gazette, for which he wrote some short stories and gained a reputation as a wonderful storyteller. He was particularly proud of a story about a man who had seduced and deserted an Indian girl who took revenge by cutting his throat from ear to ear while he slept.

He spoke little about his time in Canada with the exception of his adventures while serving in the north, especially his voyage up the Skeena river in 1905. He had been fired from his paper for inaccurate reporting of a Board of Trade meeting and signed on as an axeman with a survey party going up the Skeena river to the upper reaches of the
Bulkley river. He travelled up to Hazleton on the stern wheeler "The Royal City", working as an assistant to a Chinese cook, Tom Koo. Paying passengers were put ashore for the dangerous passage up the grand canyon. On the return journey the steamer jammed crossways in Kitselas canyon and broke in half, with half the steamer piling up at the canyon mouth. Five men were drowned.

According to an interview with a Vancouver Sun journalist in 1954, Sidney and a companion left the main party at Hazleton and returned to Port Essington in an enormous dugout manned by Indians from the missionary settlement at Meansaniskit, "the city of God", where no smoking, drinking, or swearing were allowed. Sidney had to go half a mile up river for a quiet cigarette.

At one point he and a friend went ashore in the Kisplax country, walked for hours, alarmed by the footprints of grizzly bears, spending the night up trees and listening to bears snuffling around below.

He went on several survey expeditions, sometimes acting as cook and followed the gold rush trail of 1896 in Alaska, noting the skeletons of the pack animals lying by the track, together with the many useless items of equipment that hopeful miners had abandoned, including a full sized billiard table.

From 1906 to 1909 he studied general arts at Toronto University. This course covered history and English literature and he was awarded a first class honours degree. He was an avid reader with a superb memory for poetry and the Bible and his advice to the young was to learn as much poetry as possible by the age of 20 , because this would be what they would never forget. This quality remained with him for the rest of his life and he became famous for his ability to produce an apt quotation at medical meetings. In the early years of the second world war, when invasion was anticipated, he set himself the task of learning the whole Bible so that if imprisoned he would have it in his head.

On his return from Toronto he worked for three months as news editor of the New Westminster Daily News and did some teaching at Vancouver High School. His love of teaching proved useful in the war when he received anonymous food parcels from a former grateful pupil.

In 1910 he went up to Exeter College, Oxford, as a Rhodes scholar to read natural science with medicine in view. He saw the last days of an Oxford that was to die in the mud of France. Each student had a room with a small bedroom and a coal fire, which was lit before rising by his scout. He described breakfast parties of lobster and champagne. Lectures were in the morning and not compulsory, the afternoon being free for sport or long walks with friends. He 
rowed for Exeter College, being coached by the future Archbishop of Canterbury, Geoffrey Fisher. Many young men combined the pleasures of Oxford with hard study and he was one of these. He graduated, again with a first class honours degree, in 1913, and won a scholarship to St Mary's Hospital. His love of Oxford remained with him for the rest of his life.

While working in London, like many other young colonials, he joined King Edward's Horse as a volunteer. He started the war as a trooper in the regiment described by a visiting general as "bloody rabble on horseback". He was anxious to qualify as rapidly as possible and managed to cram 18 months of clinical training into six months and qualified as Licentiate in Medicine and Surgery of Apothecaries, the lowest possible medical qualification in 1915. He proceeded to France as captain in the Royal Army Medical Corp without filling any resident hospital appointments. While in France he became interested in the subject of nephritis, and while attached for a short time to a base hospital he was able to make observations, which later resulted in several publications on "trench" nephritis.

His memories of France left him with a deep hatred of war. He remembered the jingoism of those who stayed at home and how different it was from those at the front. He once said, jokingly, that if there ever was another war he would go in the navy because at least your feet were not immersed in the mud.

In 1917 he developed pleurisy and suffered a haemoptysis, which in those days was usually a sign of tuberculosis. He was invalided home to work in the military hospital, which was housed in the examination schools in Oxford. Here began his lifelong interest in diagnostic pathology. He acted as demonstrator in pathology and bacteriology in the department of pathology of the University of Oxford, as clinical assistant to the Oxford Eye Hospital, and as temporary tutor in physiology to Exeter College, Oxford. One of his first students was a slim and beautiful woman called Janet Smith, who was rather unenthusiastically engaged to the son of a bishop. They fell in love and he asked her father's permission to marry her (fig 1). After a short engagement they were married-a khaki wedding in September 1918. On the evening before the wedding he opened his Gideon Bible in his hotel room, which fell open at the verse "thou shalt see thy children's children and peace in the land".

They returned to Oxford and set up house in Longwall Street. That winter was so cold that the water carried upstairs by the maid had frozen in the jug by the time it arrived, and the urine froze in the chamber pot! At this time the influenza epidemic was raging and many doctors died. He recalls visiting a house in a poor part of Abingdon where he had to climb over three dead bodies lying in a bed to reach the only one living. He himself picked up the infection but fortunately survived.

His continuing interest in the application of new methods in the laboratory investigation of disease and treatment led to his first appointment after the war as assistant microbiologist at the University of Durham Medical School in 1918. This post involved the teaching of bacteriology both to medical students and candidates for the diploma of public health, and the carrying out of diagnostic bacteriological work. While occupying this post he began an investigation into the prevalence of the various types of pneumococci.

\section{"While in France he became interested in the subject of nephritis, and while attached for a short time to a base hospital he was able to make observations, which later resulted in several publications on trench nephritis"}

In 1920, Sir Cuthbert Wallace, director of the surgical unit, invited him to set up a laboratory for the clinical unit at St Thomas's Hospital, London. The pathological and bacteriological laboratories were non-existent; his first duty was to establish and equip them and to arrange for a diagnostic service to be provided. The work comprised a mixture of teaching, research, and, more importantly for Sidney, clinical diagnosis. The teaching consisted of lectures and classes in morbid anatomy and histology, in clinical pathology and bacteriology, and in practical histology; in addition, individual personal instruction was given to students, who were encouraged to work in the laboratories in their own time. His research at that time was concerned mainly on the correlation between abnormalities in renal function and the morphological changes in the kidney and other organs. Other work included

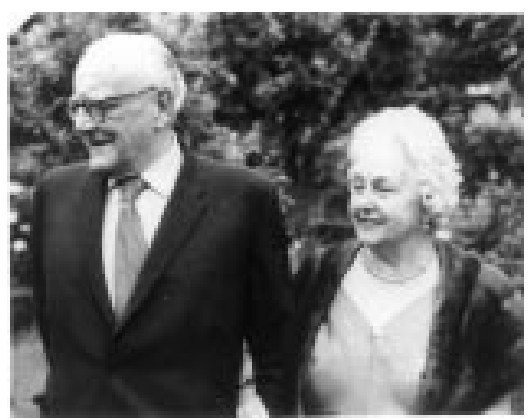

Figure 1 Sidney Dyke and his wife Janet on the occasion of their golden wedding anniversary, September 1968. the constitution, inheritance, and the general importance of the blood groups; and both alone and in collaboration with Mr BC Maybury, FRCS, he conducted experimental investigations into the routes and mode of infection of the kidneys. The results of these various projects resulted in several publications.

He was admitted to the Member of the Royal Collage of Physions in 1924 and was awarded the degree of Doctor of Medicine at the University of Oxford in the same year. He always enjoyed wearing the scarlet robes and velvet cap relevant to that degree.

Also in 1924, he was appointed pathologist and bacteriologist to the Royal Staffordshire General Hospital, which became the Royal Hospital, Wolverhampton, where he worked until his retirement in 1952. His reference from SG Shattock, FRS, for that post survives and reads as follows:

"I have known Dr SC Dyke since he was appointed pathologist to the units at St Thomas's Hospital in 1920. From my direct knowledge of his work I can say that he is, I think, an excellent pathologist of the broader type. His knowledge, both practical and theoretical, extends to all the chief branches of pathology.

He is an enthusiastic teacher and likewise an able investigator, as his experimental work on the fate of staphylococci in the kidney after intravenous injection, in the rabbit, proves. He is, moreover, a most obliging colleague and conscientious officer."

Before leaving London he had been elected Secretary to the pathological section of the Royal Society of Medicine.

The 1920s were a period of rapid advances in the scientific basis of medicine. Insulin had become available for the treatment of diabetes and liver extracts for pernicious anaemia. Sidney became especially interested in these conditions and was thrilled with the opportunity that this presented for treating diseases that were previously fatal. Another contribution to local medicine was the development of blood transfusion. He gave the first blood transfusion in his area and in 1925 collaborated with the Rotary Club to organise a voluntary transfusion service. Donors were urgently summoned by a motorcyclist, even in the middle of the night, to be rushed to hospital to save a life. By 1939, this service had developed into the Emergency Transfusion Service in anticipation of the coming war. His wife headed a team of women who went around local factories to enrol donors and take blood samples.

In 1929, he was awarded the Radcliffe Prize for the Advancement of Medicine by the University of Oxford and during the 1920s he was twice offered professorships: one in pathology at Cairo University; the other in Medicine at Chulalong 
Horn University in Bangkok. His daughter, Dr Elizabeth Howl, recalls finding a tattered canvas cot swathed in mosquito netting in the attic, which had been bought for Siam; so he must have seriously considered going.

He was always clinically orientated and established outpatient clinics for diabetes mellitus and pernicious anaemia in his laboratory, in addition to having charge of a few beds in the hospital. He believed that the place of the clinical pathologist was at the patient's bedside and not isolated in the laboratory. As he said "the impression exists that the beginning and end of clinical pathology is the examination of a specimen without reference to the patient". After their blood tests patients would queue to see him. Sometimes the queue was long, extending out of the doors, whatever the weather. Dr Thorne, his successor, remembered more than 75 patients being seen in a morning. At the end of the session Sidney would sit back, light a cigarette, and proclaim "By God, Thorne, that was a good morning's work.".

Additional publications included papers on the diagnosis of pernicious anaemia and locally he introduced the use of liver for its treatment, in addition to insulin for diabetes. Later, in 1936, he pioneered the use of sulfonamides in the treatment of pneumococcal pneumonia and meningitis, also usually previously fatal. This received some national publicity and tributes from grateful patients in newspapers.

\section{"He believed that the place of the clinical pathologist was at the patient's bedside and not isolated in the laboratory"}

Sidney's greatest claim to fame was the creation of the ACP. From its inception it met twice a year, the summer meeting in the provinces and the winter meeting in London. The early scientific meetings concentrated on scientific developments followed by discussion. He reported on the various activities of council at the business meeting, often humorously and in expressive style. The warm and relaxed mood of these meetings was long remembered by his colleagues and this acted as a magnetic attraction to attend. He regarded the dinner as a particularly important part of the meetings. There were no set speeches and no invited speakers, but it was understood that after dinner anyone was free to air his/her opinions and receive the views of fellow members. These after dinner discussions proved of the greatest value in formulating the early policies of the association. This policy continues today and has evolved to include recitations of a non-medical nature.

After each meeting he produced a detailed account of the proceedings and circulated these to all members for the benefit of those who were not able to attend. He put an enormous amount of time and enthusiasm into working for the ACP, serving as honorary secretary from 1928 to 1936, president from 1937 to 1943 , and chairman of council from 1943 to 1952. As the most active, forceful, and articulate member of the association, he invariably represented it (often with others) at meetings, committees, etc, where the views of hospital pathologists were of importance, such as the Royal College of Physicians' committee considering the Beveridge report. In 1947 he became editor of the first edition of Recent Advances in Clinical Pathology and continued this editorship through to the sixth edition in 1973.

In 1952, he gave the first triennial foundation lecture, which still bears his name, and received a gold medal with a very good likeness of himself on it. In that same year McMenemy wrote "his services to the association are so outstanding, indeed they must be unique, that the possibility of retirement seems to us who know and admire him, to be out of the question". The reports evolved to the publication of "Reports and Broadsheets" and in 1947, at a meeting in Oxford, the decision was taken to publish a journal, the Journal of Clinical Pathology; AG Signy was appointed first editor.

He knew all of the regular attenders at the meetings well, where they came from, and their interests, and was still attending meetings until shortly before his death. The question of honorary membership was considered about the time of his retirement, but was not proceeded with because it would have meant that he would have lost his right to vote.

Although short handed and working very long hours, particularly during the second world war, he remained full of hope for a better world after the war. He firmly believed that citizens from different nations and cultures were more likely to get on together if they met and spoke to each other. It was from this belief that, in the darkest hours, in 1941, he founded the European Association of Clinical Pathologists, and he became its first president. In a letter circulated to the members of the ACP touching upon the European Association he wrote as follows: "Mr Winston Churchill has pointed out the duty laid upon each and all is to strive to become 'good Europeans'. This demands an acquaintance and contact with our fellow Europeans closer than we as people have sought or has been sought from us in the past." This association evolved to become the World Association of Societies of Pathology, of which he was also the first president.

After the war he was asked to go to newly liberated Czechoslovakia to advise on pathology services, travelling in a transport Dakota, sitting on the floor, propped up against a bag.

In the years leading up to his retirement he became something of an elder statesman, travelling extensively, often accompanied by his wife, who was always elegant and charming and who enjoyed meeting so many people. They were both received in audience by the Pope. She had been a magistrate and enjoyed visiting courts and penal establishments and was sometimes addressed as "Judge Dyke".

Following the second congress of the International Society of Clinical Pathologists in Washington, USA, he and his wife paid their first visit to Vancouver since he left for Oxford in 1910.

In addition to his many medical activities he founded the Wolverhampton Civic Hall Arts Society and made a short excursion into local politics, being elected as an Independent for Tettenhall Council. He was the last man to wear the chairman's ornate chain of office, because Tettenhall merged with Wolverhampton in 1966. In 1952, the year of his retirement, he was appointed curator of the regional histological collection at Birmingham University, funded by the British Empire Cancer Campaign.

His attitude to retirement was one of disgruntlement, which might just be apparent in the official portrait that now hangs on the stairs of the Royal Hospital. He remained fully occupied, attending national and international meetings, and continued to look after a large number of devoted private patients, particularly those with diabetes. He and his wife continued to live in their solid 19th century residence facing the Upper Green in Tettenhall, surrounded by their grandchildren. He remained physically and mentally active until 1975 when he became short of breath and had developed widespread cancer. He accepted this calmly, having been a practising Christian for over 30 years. Shortly before his death the local vicar took a family house communion, attended by all the family including children and grandchildren. Afterwards they drank sherry and discussed the difference between being a devout Catholic and a staunch Protestant. At one stage Sidney had considered becoming a Catholic but could not accept the doctrine of Original Sin.

\section{"His attitude to retirement was one of disgruntlement, which might just be apparent in the official portrait that now hangs on the stairs of the Royal Hospital"}

His memory remained good to the end. Shortly before his death he quoted Kingsley's "Crossing the Bar" to his daughter, Elizabeth. 
In his "Personal recollections of Sidney Dyke in the early years of the ACP", published in the Journal of Clinical Pathology in 1966, Cuthbert E Dukes described him as a very sociable person, easy to get on with - a far sighted man, but not a mere visionary-he was a man of action with the courage of his convictions. Professor E $\mathrm{K}$ Blackburn in an article on Sidney Dyke published in the same journal in 1991, described him as "a truly great medical man whom it was a great privilege to have known-a loyal friend. The present generation of clinical pathologists owes more to him than it may realise.".

The authors and many others looking back over Dyke's life and the many years since his death fully endorse this discerning appraisal.

J Clin Pathol 2003;56:323-326

\section{Authors' affiliations}

W R Timperley, 18 Park Avenue, Dronfield, Derbyshire S1 8 2LQ, UK

J Burston, Tanyards, Rowsel's Lane, Totnes, Devon TQ9 5AG, UK

E Howl, 8 Broxwood Park, Tettenhall Wood, Wolverhampton WV6 8LZ, UK Correspondence to: Dr W R Timperley, 18 Park Avenue, Dronfield, Derbyshire S1 8 2LQ, UK; wrł@sheffield.ac.uk

\section{Clinical Evidence-Call for contributors}

Clinical Evidence is a regularly updated evidence based journal available worldwide both as a paper version and on the internet. Clinical Evidence needs to recruit a number of new contributors. Contributors are health care professionals or epidemiologists with experience in evidence based medicine and the ability to write in a concise and structured way.

Currently, we are interested in finding contributors with an interest in the following clinical areas:

Altitude sickness; Autism; Basal cell carcinoma; Breast feeding; Carbon monoxide poisoning; Cervical cancer; Cystic fibrosis; Ectopic pregnancy; Grief/bereavement; Halitosis; Hodgkins disease; Infectious mononucleosis (glandular fever); Kidney stones; Malignant melanoma (metastatic); Mesothelioma; Myeloma; Ovarian cyst; Pancreatitis (acute); Pancreatitis (chronic); Polymyalgia rheumatica; Post-partum haemorrhage; Pulmonary embolism; Recurrent miscarriage; Repetitive strain injury; Scoliosis; Seasonal affective disorder; Squint; Systemic lupus erythematosus; Testicular cancer; Varicocele; Viral meningitis; Vitiligo

However, we are always looking for others, so do not let this list discourage you.

Being a contributor involves:

- Appraising the results of literature searches (performed by our Information Specialists) to identify high quality evidence for inclusion in the journal.

- Writing to a highly structured template (about 2000-3000 words), using evidence from selected studies, within 6-8 weeks of receiving the literature search results.

- Working with Clinical Evidence Editors to ensure that the text meets rigorous epidemiological and style standards.

- Updating the text every eight months to incorporate new evidence.

- Expanding the topic to include new questions once every 12-18 months.

If you would like to become a contributor for Clinical Evidence or require more information about what this involves please send your contact details and a copy of your CV, clearly stating the clinical area you are interested in, to Claire Folkes (cfolkes@bmigroup.com).

\section{Call for peer reviewers}

Clinical Evidence also needs to recruit a number of new peer reviewers specifically with an interest in the clinical areas stated above, and also others related to general practice. Peer reviewers are health care professionals or epidemiologists with experience in evidence based medicine. As a peer reviewer you would be asked for your views on the clinical relevance, validity, and accessibility of specific topics within the journal, and their usefulness to the intended audience (international generalists and health care professionals, possibly with limited statistical knowledge). Topics are usually 2000-3000 words in length and we would ask you to review between 2-5 topics per year. The peer review process takes place throughout the year, and our turnaround time for each review is ideally 10-1 4 days.

If you are interested in becoming a peer reviewer for Clinical Evidence, please complete the peer review questionnaire at www.clinicalevidence.com or contact Claire Folkes (cfolkes@bmigroup.com). 